\title{
Women on boards
}

\section{Leyre Maiso Fontecha}

(C) ERA 2013

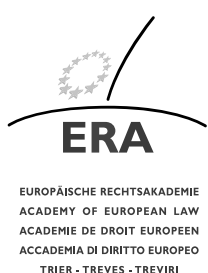

\section{Legal Framework}

Equality between women and men is one of the fundamental principles of EU law. It has been part of Union law since the signing of the Treaty of Rome in 1957. Since then, a considerable number of Directives have been adopted on matters such as equal treatment in employment and occupation, including self employment, health protection in the maternity context, parental leave or access to goods and services.

EU equality law recognises the principle of positive action in Article 157(4) of the TFEU, which reads:

"With a view to ensuring full equality in practice between men and women in working life, the principle of equal treatment shall not prevent any Member State from maintaining or adopting measures providing for specific advantages in order to make it easier for the under-represented sex to pursue a vocational activity or to prevent or compensate for disadvantages in professional careers."

Similarly, Article 23 of the EU Charter of Fundamental Rights states:

"Equality between women and men must be ensured in all areas, including employment, work and pay. The principle of equality shall not prevent the maintenance or adoption of measures providing for specific advantages in favour of the under-represented sex."

L. Maiso Fontecha $(\bowtie)$

Deputy Head of Section, European Private Law section, ERA Academy of European Law, Metzer Allee 4, 54295 Trier, Germany

e-mail:1maiso@era.int 
The aim of positive action is to achieve substantive, rather than formal, equality by reducing de facto inequalities which may arise in society and, thus, to prevent or compensate for disadvantages in the professional career of the persons concerned. ${ }^{1}$ Positive action measures can include equal opportunities plans, targets and quotas for promotion or recruitment, measures tending to facilitate vocational training for women, financial incentives, good practices rewards, etc.

The Court of Justice of the European Union in its jurisprudence has dealt with different positive action measures and their compatibility with EU law. Although it is not easy to extract clear guiding principles from the case law, it is safe to say that one of the key rulings is that national laws which guarantee women absolute and unconditional priority in respect of appointments or promotion in sectors in which they are under-represented go beyond the limits of the exception allowed by EU law. ${ }^{2}$ The Court further explained in its Badeck judgment ${ }^{3}$ the conditions under which national quota systems are permissible:

(a) they apply only when male and female candidates have equal qualifications;

(b) they must contain a saving clause that allows to take account of specific personal situations of candidates from the "dominant group" and;

(c) they must have a temporally limited application.

\section{The Commission Proposal}

The debate on gender quotas has become increasingly present at European level ${ }^{4}$ as a means to address the lack of female participation in economic decision-making. According to EU data, in January 2012, women represented only $13.7 \%$ of persons in board positions of the largest publicly listed companies. ${ }^{5}$ After several attempts in the last decade to increase the number of women in business through voluntary commitments, ${ }^{6}$ the European Commission adopted on 14 November 2012 a legislative proposal "on improving the gender balance among non-executive directors of companies listed on stock exchanges and related measures". ${ }^{7}$

The core of this highly debated proposal is the imposition of a $40 \%$ gender quota for non-executive directors in EU listed companies by 2020. The $40 \%$ target is binding, but there are no sanctions for not reaching this goal. Only EU companies listed

\footnotetext{
${ }^{1}$ See for example CJEU cases C-407/98 Abrahamsson [2000] ECR I-05539 and C-319/03 Briheche [2004] ECR I-08807.

${ }^{2}$ Case C-450/93 Kalanke [1995] ECR I-03051.

${ }^{3}$ Case C-158/97 Badeck, [2000] ECR I-01875.

${ }^{4}$ In particular: Strategy for Equality between Women and Men 2010-2015. COM(2010) 491 final.

${ }^{5}$ See Progress report: Women in economic decision-making in the EU, March 2012 (http://ec.europa.eu/ justice/gender-equality/files/women-on-boards_en.pdf).

6"Women on the Board Pledge for Europe" (http://ec.europa.eu/commission_2010-2014/reding/ womenpledge/index_en.htm).

${ }^{7} \mathrm{COM}(2012) 614$ final.
} 
on EU stock exchanges are affected, ${ }^{8}$ be they privately or publicly owned, ${ }^{9}$ with the exception of small and medium-sized companies. ${ }^{10}$ It is estimated that the proposal will apply to around 5,000 companies. ${ }^{11}$ This $40 \%$ quantitative objective is combined with binding rules on a transparent selection process. Article 4(1) reads:

"Member States shall ensure that listed companies in whose boards members of the under-represented sex hold less than 40 per cent of the non-executive director positions make the appointments to those positions on the basis of a comparative analysis of the qualifications of each candidate, by applying preestablished, clear, neutrally formulated and unambiguous criteria, in order to attain the said percentage at the latest by 1 January 2020 or at the latest by 1 January 2018 in case of listed companies which are public undertakings."

It should be clearly noted that according to the Commission proposal, the appointment procedure must be based on merit. It is only in case of equal qualifications of the candidates, that the preference rule of Article 4(3) would apply, and it does so with a saving clause, in accordance with the CJEU case-law:

“... priority shall be given to the candidate of the under-represented sex if that candidate is equally qualified as a candidate of the other sex in terms of suitability, competence and professional performance, unless an objective assessment taking account of all criteria specific to the individual candidates tilts the balance in favour of the candidate of the other sex".

Companies are also required to disclose to unsuccessful candidates, upon request, the selection criteria used. ${ }^{12}$ In addition, if a presumption of equal qualifications can be established, it is for the companies to prove that there has been no breach of the preference rule. $^{13}$

Regarding executive directors, ${ }^{14}$ the proposal also includes an obligation for listed companies to set themselves individual, self-regulatory targets, the so-called "flexiquota". There are no procedural obligations related to appointments, but the same deadlines and reporting obligations as for non-executive directors apply.

As mentioned, sanctions will not be imposed for not reaching the $40 \%$ objective but for breaches of the obligations set out in the Directive, ${ }^{15}$ that is:

- for non-executives directors: in case of non-compliance with the procedural obligations;

\footnotetext{
${ }^{8}$ See Art. 2(1).

${ }^{9}$ Public undertakings as defined in Art. 2(9).

${ }^{10}$ See Art. 3, as defined in Art. 2(8).

${ }^{11}$ European Commission MEMO/12/860: Questions and Answers: Proposal on increasing Gender Equality in the Boardrooms of Listed Companies (14 November 2012).

${ }^{12}$ See Art. 4(4).

${ }^{13}$ See Art. 4(5).

${ }^{14}$ See Art. 5(1).

${ }^{15}$ See Art. 6.
} 
- for executives directors: in case of non-compliance with the obligation to set individual objectives;

- for both: for non-compliance with the reporting and monitoring obligations.

It is for the Member States to define what kind of sanctions will apply as long as they are effective, proportionate and dissuasive. Reportedly, Commissioner Reding had initially sought to impose more stringent sanctions but the legal basis for doing so was queried by the Commission's legal service.

There is a high degree of flexibility in the Commission proposal. For instance, if the under-represented sex holds at least one third $(=33 \%)$ of all (executive and non-executive) director positions, the $40 \%$ objective of Art. 4(1) is considered to be met. ${ }^{16}$ Also, Member States may provide for an exception for those companies whose workforce is predominantly of one sex (= less than $10 \%$ of the other sex). ${ }^{17}$ Finally, the Commission proposal includes a sunset clause limiting temporarily the application of the Directive which shall expire on 31 December 2028. ${ }^{18}$

Overall, the proposal of the Commission is well balanced, leaving enough flexibility for Member States and companies and is, from a legal point of view, consistent with EU law. Interestingly, the word "quota" does not appear in the text of the proposed Directive, which is also couched in gender neutral terminology.

It goes without saying that the best-qualified person should get the job. Nonetheless, many women have achieved the highest qualifications and yet they still remain poorly represented on boards. This raises legitimate questions concerning how board recruitments are made. Previous attempts to address the status quo by using voluntary targets haven't brought about any substantial change. Are quotas therefore a "necessary evil"?

\footnotetext{
${ }^{16}$ See Art. 4 (7).

${ }^{17}$ See Art. 4(6).

${ }^{18}$ See Art. $10(2)$ 